\title{
Molecular prognostic markers for adult acute myeloid leukemia
} with normal cytogenetics

\author{
Tara K Gregory ${ }^{1}$, David Wald ${ }^{2}$, Yichu Chen ${ }^{1}$, Johanna M Vermaat ${ }^{2}$, \\ Yin Xiong ${ }^{1}$ and William Tse*1
}

\begin{abstract}
Address: ${ }^{1}$ Division of Medical Oncology, University of Colorado Cancer Center, University of Colorado School of Medicine, Aurora, Colorado, USA and '2Department of Medicine, Case Western Reserve University, Cleveland, Ohio, USA

Email: Tara K Gregory - tara.gregory@ucdenver.edu; David Wald - david.wald@case.edu; Yichu Chen - chapman.c@tom.com; Johanna M Vermaat - j.m.van.antwerpen@umail.leidenuniv.nl; Yin Xiong - yin.xiong@ucdenver.edu; William Tse* - william.tse@ucdenver.edu * Corresponding author
\end{abstract}

Published: 2 June 2009

Journal of Hematology \& Oncology 2009, 2:23 doi:10.1 186/1756-8722-2-23
Received: 31 March 2009

Accepted: 2 June 2009

This article is available from: http://www.jhoonline.org/content/2/I/23

(c) 2009 Gregory et al; licensee BioMed Central Ltd.

This is an Open Access article distributed under the terms of the Creative Commons Attribution License (http://creativecommons.org/licenses/by/2.0), which permits unrestricted use, distribution, and reproduction in any medium, provided the original work is properly cited.

\begin{abstract}
Acute myeloid leukemia (AML) is a heterogenous disorder that results from a block in the differentiation of hematopoietic progenitor cells along with uncontrolled proliferation. In approximately $60 \%$ of cases, specific recurrent chromosomal aberrations can be identified by modern cytogenetic techniques. This cytogenetic information is the single most important tool to classify patients at their initial diagnosis into three prognostic categories: favorable, intermediate, and poor risk. Currently, favorable risk AML patients are usually treated with contemporary chemotherapy while poor risk AML patients receive allogeneic stem cell transplantation if suitable stem cell donors exist. The largest subgroup of AML patients $(\sim 40 \%)$ have no identifiable cytogenetic abnormalities and are classified as intermediate risk. The optimal therapeutic strategies for these patients are still largely unclear. Recently, it is becoming increasingly evident that it is possible to identify a subgroup of poorer risk patients among those with normal cytogenic AML (NC-AML). Molecular risk stratification for NC-AML patients may be possible due to mutations of NPMI, FLT3, MLL, and CEBP $\alpha$ as well as alterations in expression levels of BAALC, MNI, ERG, and AFI q. Further prospective studies are needed to confirm if poorer risk NC-AML patients have improved clinical outcomes after more aggressive therapy.
\end{abstract}

\section{Introduction}

Acute Myeloid Leukemia (AML) is a broad range of disorders that are all characterized by an arrest of maturation along with uncontrollable proliferation of hematopoietic progenitor cells. The French-American-British classification is still widely used in clinical setting that groups AML into 8 subgroups (MO-M7) based on its degree of differentiation and morphology. Due to the heterogenous nature of AML even within specific FAB subtypes, there is a highly variable prognosis among AML patients. The overall 5year survival rate for AML is still less than $50 \%$ in adults and significantly lower in the elderly [1]. The median survival in patients over the age of 65 is less than one year and only $20 \%$ of these patients survive two years [2]. Treatment for all subtypes of AML, except the M3 subtype, involves combination chemotherapy and a possible hematopoietic stem cell transplant as part of consolidation therapy. Acute Promyelocytic Leukemia (APL, M3 subtype) is treated with a combination of the differentiation-inducing agent all-trans retinoic acid and chemotherapy resulting in the presumed cure of $75-85 \%$ of patients [3]. In general, the prognosis of patients with AML is cur- 
rently based upon the presence or absence of cytogenetic abnormalities and is divided into favorable, intermediate and unfavorable subgroups (see table 1) [4]. There is heterogeneity within these subgroups, especially the intermediate subgroup, and the age of the patient is also an important prognostic factor. One study estimated the 5 year overall survival (OS) of the favorable subgroup at $55 \%$, the intermediate subgroup at $38 \%$ and the unfavorable subgroup at $11 \%$ [5]. Patients who have the following cytogenetic abnormalities: $\operatorname{inv}(16), \mathrm{t}(15 ; 17)$ (the translocation found in APL), or $\mathrm{t}(8 ; 21)$ have a favorable prognosis while patients with several other cytogenetic abnormalities including monosomy 5, monosomy 7, $11 \mathrm{q} 23$, and complex cytogenetics may have a poor prognosis. However, approximately $40 \%$ of AML patients have no identifiable cytogenetic abnormality by using modern cytogenetic and fluorescence in-situ hybridization (FISH) methods. These patients are usually classified as an intermediate risk group. Although the NC-AML patients are currently considered as having an intermediate prognosis, these patients have a wide range of overall survival rates between $24 \%$ to $42 \%$. Recently, multiple institutions from Europe and the United States conducted retrospective studies which showed some molecular markers that could identify good and poor risk NC-AML patients and suggest that these patients should be treated accordingly. This review encompasses a discussion of the molecular markers in NC-AML which are mutations (NPM1, FLT3, MLL-PTD, CEPB $\alpha$ ) and those that are a function of overexpression (BAALC, MN1, ERG-1, AF1q). These differences in markers of mutation versus over-expression are summarized in Table 1. Furthermore, some of the genetic abnormalities have also been found to be useful for minimum residual disease monitoring and as potential therapeutic targets.

Table I: Genetic Abnormalities in Normal Cytogenetic AML

\begin{tabular}{llll}
\hline Name & Prognosis & Prevalence & Expression \\
\hline NPM-I & Favorable & $50-60 \%$ & Mutation \\
\hline FLT3-ITD & Unfavorable & $30-40 \%$ & Mutation \\
\hline FLT3-Asp835 & Unclear & $5-10 \%$ & Mutation \\
\hline BAALC & Unfavorable & $65.7 \%$ & Over expression \\
\hline MNI & Unfavorable & $50 \%$ & Over expression \\
\hline MLL-PTD & Unfavorable & $7.7 \%$ & Mutation/over expression \\
\hline CEBP $\alpha$ & Favorable & $15-20 \%$ & Mutation \\
\hline ERG-I & Unfavorable & $25 \%$ & Over expression \\
\hline AFIq & Unfavorable & $75 \%$ & Over expression \\
\hline
\end{tabular}

\section{The Nucleophosmin Gene (NPMI)}

Mutations of NPM1 have recently been described as one of the most frequent genetic lesions in $\mathrm{AML}$, occurring in $50-60 \%$ of adult AML with normal karyotype [6,7]. Additional evaluation has shown that mutations in NPM1 are rare in other risk groups of AML and in one study, no NPM1 mutations were shown in patients with favorable cytogenetics [7]. The NPM1 gene encodes a nucleo-cytoplasmic shuttling protein that regulates the ARF-p53 tumor-supressor pathway $[8,9]$. Mutations in this gene result in an abnormal accumulation of the NPM1 protein in cytoplasm. Two types of mutations have been described to date. The first and most frequent mutations consists of a 4-nucleotide (nt) insertion (YWTG; YUPAC code) downstream from nucleotide 959; the second is deletion of a GGAGG sequence at positions 965 through 969 and substitution with 9 extra nt (GenBank accession no. NM 002520). Both mutations lead to aberrant cytoplasmic localization of NPM1 as shown after immunostaining with anti-NPM1 monoclonal antibodies. This is caused by open reading frameshift mutations that lead to either the disruption of the NPM1 nucleolar-localization signal or the generation of a leucine-rich nuclear export motif. In all mutated cases, the resulting frameshift led to a product five amino acids longer with the new C-terminal tail CFSQVSLRK, peculiar to the NPM1-mutated product [7].

Recent studies in cell lines and knockout mice have shown that NPM1 is involved in the control of genomic stability and contributes to growth-suppressing pathways through its interaction with ARF. Therefore, the loss of NPM1 expression can contribute to tumorgenesis [10]. Several methods are suitable for detecting NPM1 gene mutation, including molecular and immunohistochemical studies [7,11-13].

NPM1 gene mutations appear to occur more frequently in adult female AML patients [14-16] and also tend to be associated with: a) higher white blood cell count, b) monocytic differentiation (in particular FAB M5b AML subtype) [17], c) wide morphologic spectrum, d) multilineage involvement [9], e) lack of CD34/CD34-negativity $[7,9,11]$, f) normal cytogenetics [18], g) a decreased prevalence of CEBP $\alpha$ mutations [17], h) high frequency of FLT3-ITD gene mutation [18] and i) a trend toward favorable clinical outcome, especially in patients without a FLT3 gene mutation $[7,15]$. Patients with only an NPM1 mutation exhibit higher complete remission (CR) and significantly better OS [14-16], event free survival (EFS) [15], and disease free survival (DFS) as well as a lower cumulative incidence of relapse $[6,16]$. The various study outcomes of risk associated with NPM1 status are summarized in Table 2.

Detection of NPM1 gene mutations may be useful in the dissection of the heterogeneous group of AML patients 
with normal karyotype into prognostically different subgroups [7]. Further, due to their frequency and stability, NPM1 mutations may become a new tool for monitoring minimal residual disease in AML-patients with a normal karyotype [9].

\section{The Fms-like tyrosine kinase 3 Gene (FLT3)}

FLT3 is a tyrosine kinase that is primarily expressed on hematopoietic progenitor cells and functions in the proliferation and differentiation of these cells. FLT3 is the most commonly mutated gene in AML with the mutation occurring in approximately $30-40 \%$ of AML patients [19].
The most common mutation consists of an internal tandem duplication (FLT3-ITD) in the juxtamembrane domain of the FLT3 gene. FLT3-ITD results in a constitutively active FLT3 protein that promotes Stat 5 phosphorylation. The net consequence of FLT3/Stat 5 constitutive activation is uncontrolled hematopoietic cell proliferation [20]. AML patients who carry the FLT3-ITD mutation appear to have poorer clinical outcomes. Adult patients usually have a higher prevalence of FLT3-ITD than pediatric AML patients. This observation may partially explain why adult AML has a poorer clinical outcome than pediatric AML. Clinically, AML patients with FLT3-ITD tend to

Table 2: NPMI Mutant Risk Assessment

\begin{tabular}{|c|c|c|c|c|}
\hline Study & $\begin{array}{l}\text { Number of NPMI mutants/ } \\
\text { total cases studied }\end{array}$ & Treatment & $\begin{array}{l}\text { Demographics of those } \\
\text { patients with NMPI } \\
\text { mutations }\end{array}$ & $\begin{array}{l}+ \text { NPMI mutant assessment } \\
\text { of risk }\end{array}$ \\
\hline Verhaak, et al [6] & $\begin{array}{l}95 / 275 \\
(34.5 \%)\end{array}$ & $\begin{array}{l}\text { Dutch Belgian Hematology } \\
\text { Oncology Cooperative Groop } \\
\text { (HOVON) protocols }\end{array}$ & $\begin{array}{l}\text { - Median age } 47 \text { yo } \\
-60 \% \text { of those with FLT3 } \\
\text { ITD } \\
\text { - decreased in those age < } \\
35 \text { yo } \\
-42 \% \text { of those with WBC } \\
>20 \mathrm{~K}\end{array}$ & $\begin{array}{l}\text { HR } \\
\text { EFS } 1.96 \\
\text { DFS } 2.0 \\
\text { OS } 2.13\end{array}$ \\
\hline Döhner, et al [14] & $\begin{array}{l}145 / 300 \\
(48.3 \%)\end{array}$ & $\begin{array}{l}\text { AML Study Group (AMLSG) } \\
\text { AML HD93 } \\
\text { AML HD98-A }\end{array}$ & $\begin{array}{l}\text { - Increased in M4/M5 } \\
\text { - extramedullary LAD } \\
\text { - Female predominance } \\
\text { - Decreased CD34 antigen } \\
\text { expression } \\
\text { - Increased LDH } \\
\text { - Associated with FLT3 ITD } \\
\text { - WBC }>20 \mathrm{~K} \\
\text { - Increased bone marrow } \\
\text { blast counts }\end{array}$ & $\begin{array}{l}\text { Odds ratio (OR) after } \\
\text { induction } \\
\text { CR 2.8I }\end{array}$ \\
\hline Schnittger, et al [15] & $\begin{array}{l}212 / 401 \\
(52.9 \%)\end{array}$ & German AMLCG99 study & $\begin{array}{l}\text { - Associated with FLT3 ITD } \\
\text { - Without FLT3, OS and EFS } \\
\text { increased } \\
\text { - Female predominance }\end{array}$ & $\begin{array}{l}\text { Relative risk (RR) } \\
\text { EFS } 0.527\end{array}$ \\
\hline Theide, et al [16] & $\begin{array}{l}408 / 1485 \\
(27.5 \%)\end{array}$ & $\begin{array}{l}\text { Deutsche Studieninitiative } \\
\text { Leukämie (DSIL) AML } 96 \\
\text { protocol }\end{array}$ & $\begin{array}{l}\text { - High bone marrow blasts } \\
\text { - Female predominance } \\
\text { - WBC > } 20 \mathrm{~K} \\
\text { - Association with FLT3-ITD } \\
\text { mutations }\end{array}$ & $\begin{array}{l}\text { OR } \\
\text { OS } 0.76 \\
\text { DFS } 0.66\end{array}$ \\
\hline Boissel, et al [17] & $\begin{array}{l}50 / 106 \\
(47 \%)\end{array}$ & $\begin{array}{l}\text { French Leukemia French } \\
\text { Association (ALFA) } \\
\text { ALFA90 } \\
\text { ALFA9802 }\end{array}$ & $\begin{array}{l}\text { - Increased in FAB M4/M5 } \\
\text { - } 25 \% \text { with FLT3-ITD } \\
\text { - Decreased CEBPA } \\
\text { - WBC > } 20 \mathrm{~K}\end{array}$ & $\begin{array}{l}\text { No difference in CR or long } \\
\text { term outcomes }\end{array}$ \\
\hline Suzuki, et al [18] & $\begin{array}{l}64 / 257 \\
(24.9 \%)\end{array}$ & $\begin{array}{l}\text { Japan Adult Leukemia Study } \\
\text { Group protocols }\end{array}$ & - Associated with FLT3-ITD & $\begin{array}{l}\text { - NPMI mutant unfavorable } \\
\text { factor for relapse } \\
\text { OR } 2.106 \\
\text { - NPMI wild type } \\
\text { unfavorable for CR } \\
\text { OR } 4.908 \\
\text {-NPMI mutant with FLT3- } \\
\text { ITD favorable for CR } \\
\text { OR } 20.8\end{array}$ \\
\hline
\end{tabular}


have higher WBC counts and an increase percentage of leukemic blasts [21]. A missense mutation in the activation loop (FLT3-ALM) of the second tyrosine kinase domain of FLT3 at Asp835 leads to another common FLT3 mutant (FLT3-TKD) that is found in approximately 5$10 \%$ of AML patients [22]. Although the clinical significance of this FLT3 mutation especially in NC-AML is not yet clear, several studies indicate that it is also an adverse prognostic indicator $[19,21]$. The associated risk of FLT3 status determined by these studies are summarized in Table 3.

Particularly in AML patients with normal cytogenetics, FLT3-ITD status is important in assessing the prognosis of patients. Several studies have demonstrated that FLT3-ITD in NC-AML patients correlates with an adverse prognosis for both DFS and OS [23-25]. Not only does the presence of FLT3-ITD impart a poor prognosis, but the size of the internal tandem duplication is significant. The duplication can range in size from three to hundreds of nucleotides and longer duplications correlate with a worse OS [26]. In addition to the mutant allele, the status of the wild-type allele in patients with FLT3-ITD has been demonstrated to have prognostic significance. Patients who lack the wild-type allele have a worse prognosis [27]. In those who express the wild-type allele, the ratio of the mutant to wild-type level of FLT3-ITD has a strong correlation to survival. In one study, patients with a high mutant to wild-type ratio (defined as greater than 0.78) had a significantly shorter OS and DFS than those with a

Table 3: Positive FLT3-ITD Risk Assessment

\begin{tabular}{|c|c|c|c|c|}
\hline Study & $\begin{array}{l}\text { Number of FLT3 mutants/ } \\
\text { total cases studied }\end{array}$ & Treatment & $\begin{array}{l}\text { Demographics of those } \\
\text { patients with FLT3-ITD }\end{array}$ & $\begin{array}{l}\text { + FLT3-ITD assessment of } \\
\text { risk }\end{array}$ \\
\hline Fröhling, et al [2I] & $\begin{array}{l}\text { I I } 9 / 523 \text { all comers } \\
(22.8 \%) \\
71 / 224 \mathrm{NC} \mathrm{AML} \\
(32 \%)\end{array}$ & $\begin{array}{l}\text { AML Study Group (AMLSG) } \\
\text { AML HD93 } \\
\text { AML HD98-A }\end{array}$ & $\begin{array}{l}\text { - Associated with high WBC } \\
\text { - Associated with de novo } \\
\text { AML } \\
\text { - Increased bone marrow and } \\
\text { peripheral blood blasts } \\
\text { - Increased LDH }\end{array}$ & $\begin{array}{l}\text { Hazard ratio }(\mathrm{HR}) \\
\text { Remission duration } \\
2.35\end{array}$ \\
\hline $\begin{array}{l}\text { Kainz, et al } \\
{[23]}\end{array}$ & $\begin{array}{l}26 / 100 \\
(26 \%) \\
16 / 53 \text { NC AML } \\
(30 \%)\end{array}$ & Various protocols & $\begin{array}{l}\text { - Increased in M4 (50\%) } \\
\text { - Increased LDH } \\
\text { - WBC > } 10 \mathrm{~K}\end{array}$ & $\begin{array}{l}\text { OR } \\
\text { CR } 0.31 \\
\text { Relapse rate } 8.3 \\
\text { OS } 0.17\end{array}$ \\
\hline $\begin{array}{l}\text { Ciolli, et al } \\
{[24]}\end{array}$ & $\begin{array}{l}25 / 100 \\
(25 \%)\end{array}$ & Various protocols & $\begin{array}{l}\text { - WBC > } 30 \mathrm{~K} \\
\text { - Decreased incidence of } \\
\text { secondary AML } \\
\text { - Female predominance } \\
\text { - Increased LDH }\end{array}$ & $\begin{array}{l}\text { HR } \\
\text { RFS } 3.1 \\
\text { Post remission survival } 2.1\end{array}$ \\
\hline Stirewelt, et al [26] & $\begin{array}{l}48 / 151 \\
(31.8 \%)\end{array}$ & $\begin{array}{l}\text { Southwest Oncology Group } \\
\text { SWOG } 9333 \\
\text { SWOG } 9500\end{array}$ & $\begin{array}{l}\text { - High bone marrow blasts } \\
\text { - High peripheral blood blasts } \\
\text { - WBC >30 K }\end{array}$ & $\begin{array}{l}\text { HR } \\
\text { OS I.35 } \\
\text { RFS I.7 }\end{array}$ \\
\hline Whitman, et al [27] & $\begin{array}{l}23 / 82 \\
(28 \%)\end{array}$ & CALGB protocol & $\begin{array}{l}\text { - All patients evaluated had } \\
\text { NC AML, age }<60 \text {, and de } \\
\text { novo AML } \\
\text { - Median age } 37 \text { yo } \\
\text { - } N=8 \text { FLT3ITD/- }\end{array}$ & $\begin{array}{l}\text { No clear evidence in } \\
\text { difference between groups, } \\
\text { but trend towards decreased } \\
\text { OS with FLT3ITD/- }\end{array}$ \\
\hline Thiede, et al [28] & $\begin{array}{l}200 / 979 \\
(20.4 \%)\end{array}$ & Various protocols & $\begin{array}{l}\text { - Increased in M5 } \\
\text { - WBC >50 K } \\
\text { - Increased bone marrow } \\
\text { blasts }\end{array}$ & $\begin{array}{l}\text { OR } \\
\text { Mut/wt ratio I } \\
\text { - all ages } \\
\text { OS I.8 } \\
\text { DFS } 3.2 \\
\text { - age }<60 \\
\text { DFS } 4.2 \\
\text { Mut/wt ratio } 2 \\
\text { - all ages } \\
\text { OS } 2.8 \\
\text { DFS } 8 \\
\text { - age }<60 \\
\text { DFS6.9 }\end{array}$ \\
\hline
\end{tabular}


lower ratio. The DFS and OS for patients with a lower ratio were no different than the group of patients without FLT3 abnormalities [28].

In addition to mutation of FLT3 and the decreased expression of the wild-type allele, over-expression of FLT3 in the absence of mutation has also been observed in AML patients. Over-expression of FLT3 even in the absence of FLT3-ITD is also an unfavorable prognostic factor for OS [29]. As FLT3-ITD is an adverse prognostic factor, it has been speculated that patients with this genetic abnormality should be considered for more intensive therapy. However, a large study of 1135 adult patients with AML including 25\% with FLT3-ITD, there was no improvement in outcome based upon whether or not a patient with FLT3-ITD received a transplant in first complete remission [30].

The association of FLT3 mutations have also been evaluated in patients with favorable cytogenetics $(\mathrm{t}(8 ; 21)$, inv16, $\mathrm{t}(15 ; 17))$. FLT3 mutations were noted in 15 of 17 patients studied. Of these patients, $41 \%$ of those with $\mathrm{t}(15 ; 17)$ were associated with FLT3 mutations and only $9 \%$ of cases with inv16. Those with PML-RAR $\alpha$ had decreased to no CD11c or HLA-DR expression. However, this study did not illustrate significant correlations with outcomes and FLT3 mutational status [31].

As FLT3 mutations lead to constitutively activated signaling, much work has been performed to develop small molecule FLT3 inhibitors. Unfortunately FLT3 inhibitors have thus far shown disappointing results as remission induction has been short lived. Nevertheless, there is optimism that FLT3 inhibitors may be more efficacious when used in combination therapies [32]. Besides being a useful as a prognostic marker and a therapeutic target, FLT3-ITD has also been used for minimal residual disease monitoring [33].

\section{The mixed lineage leukemia gene (MLL)}

MLL is frequently rearranged in AML and ALL and has been found in combination with greater than 30 different genes. The most frequent rearrangements in the current published series were unbalanced translocations leading to loss of chromosomal material. Overall, loss of 5q and/ or $7 \mathrm{q}$ chromosomal material seemed the more common event, and losses of $5 q, 7 q$, and $17 p$ in combination were observed in many cases. Overrepresented chromosomal material from $8 \mathrm{q}, 11 \mathrm{q} 23,21 \mathrm{q}$, and $22 \mathrm{q}$ was found recurrently and in several cases this was due to the amplification of the MLL (located at 11q23) and AML1/RUNX1 (located at 22q22) genes [34]. MLL encodes a histone methyltransferase that plays a role in hematopoiesis by regulating homeobox genes. In mice heterozygous for MLL, both hematopoietic abnormalities are found as well as decreased Hox gene expression [35].
In addition to rearrangements, the MLL gene can also undergo partial tandem duplications of exons 5-11 or exons 5-12 and produce an elongated protein. This abnormal protein, which contains a DNA-binding and transcriptional repression domain, can suppress the expression of the wild-type allele by an unknown mechanism. Interestingly, the silencing of wild-type MLL in blasts positive for MLL-PTD was reversed by DNA methyltransferase and histone deacetylase inhibitors [36]. These findings indicate the potential therapeutic role of the DNA methyltransferase and histone deacetylase inhibitors such as decitabine and valpoic acid in these AML patients.

In one large study of 247 young adult patients with $\mathrm{AML}$, MLL-PTD was found in $7.7 \%$ of patients. In this study, MLL-PTD was an adverse prognostic indicator as the median remission duration was 19 months in the absence of MLL-PTD and 7.75 months in its presence [37]. In general, the majority of studies indicate that MLL-PTD is poor prognostic indicator in NC-AML including median survival and relapse-free interval [38]. Additionally, the use of MLL-PTD for minimal residual disease monitoring has been shown to be effective in detecting relapse prior to clinical manifestations [39].

\section{The CCAT/Enhancer Binding Protein Alpha Gene (CEBP $\alpha$ )} CEBP $\alpha$ is an essential transcription factor for granulocytic differentiation as demonstrated by CEBP $\alpha$-null mice that lack mature granulocytes $[40,41]$. Studies have reported $\mathrm{N}$ - and C-terminal CEBP $\alpha$ mutations in approximately $15 \%$ to $20 \%$ of AML [42]. The mutant proteins act in a dominant-negative manner to block DNA binding and transactivation of granulocyte target genes resulting in the failure of granulocytic differentiation [40]. Patients with a CEBP $\alpha$ mutation have higher hemoglobin levels, lower platelet counts, higher blast counts, and are less likely to present with lymphadenopathy or extramedullary leukemia compared to patients without a CEBP $\alpha$ mutation.

Suprisingly, as CEBP $\alpha$ is required for differentiation, mutation of CEBP $\alpha$ is correlated with beneficial effects on remission, CR duration [42], event-free survival [17], DFS [25], and OS [41]. While there is no significant difference in CR rates between patients with and without CEBP $\alpha$ mutations $[25,42]$, mutations are associated with a significantly reduced hazard ratio for death and event free survival [41]. CEBP $\alpha$ mutations appear to be an independent prognostic factor even in the presence of FLT3 and MLL mutations. Studies have shown that there is no significant overlap between the patients with CEBP $\alpha$ mutation and patients with FLT3-ITD or MLL-PTD mutations, suggesting that CEBP $\alpha$ mutations define a distinct biologic subclass of NC-AML [42]. CEBP $\alpha$ mutation is an independent prognostic marker for OS irrespective of age, MLL-PTD, and FLT3-ITD status [43] and is another marker that per- 
mits the division of NC-AML into distinct clinical groups [25].

While NPM1, FLT3, MLL-PTD, CEPB $\alpha$ are all mutations noted in NC-AML, additional genetic abnormalities are noted in the form of over-expression. More detailed discussion of BAALC, MN1, ERG-1, and AF1q give insight to over-expression of genes in NC-AML.

\section{The Brain and Acute Leukemia Cytoplasmic (BAALC)}

BAALC has also been found to be an important adverse prognostic factor in NC-AML. Though little is known about the biological function of BAALC, it is highly expressed in hematopoietic precursor cells as well as leukemic blasts and is down-regulated during differentiation. BAALC has been postulated to function in the cytoskeleton network due to its cellular location [44,45]. Several studies have demonstrated that high BAALC expression is a poor prognostic indicator in NC-AML for such factors as OS, DFS, and resistant disease $[46,47]$. In one study of $86 \mathrm{AML}$ patients with NC-AML, high expression of BAALC was found to be an independent risk factor for both inferior OS (1.7 vs. 5.8 years) and DFS (1.4 vs 7.3 years). Different post-remission strategies among patients with different level of BAALC expression (consolidation, autologous and allogeneic stem cell transplantation) have no influence on OS. However, high BAALC expressive patients who underwent allogeneic stem cell transplantation have lower cumulative relapse rate compared to those who underwent autologous stem cell transplantation [47].

\section{Meningioma I (MNI)}

MN1 is an oncoprotein that has been found to function as a transcription coactivator. In AML it has been found as part of the translocation $\mathrm{t}(12 ; 22)(\mathrm{p} 13 ; \mathrm{q} 11)$ which leads to the MN1-TEL fusion gene [48]. In animal models, the MN1-TEL fusion gene collaborates with HOXA9 to induce AML [49]. Recently, high levels of expression of MN1 have been found to be a prognostic marker in NC-AML. Though the exact function of MN1 in hematopoietic cells is unclear, it is another protein that is highly expressed in hematopoietic cells and is down-regulated during differentiation. In a study of 142 adult patients with NC-AML, high MN1 expression was significantly related to unmutated NPM1, poor response to initial induction chemotherapy, high relapse rate, risk free survival, and OS. In multivariate analysis, high MN1 expression was an independent prognostic marker [50].

\section{The ETS-related gene (ERG)}

ERG is a member of the ETS family of transcription factors. High ERG expression is associated with the upregulation of many genes which are involved in cell proliferation, differentiation, and apoptosis [51]. The
ERG gene is a recently identified molecular marker predicting adverse outcome of NC-AML patients. Overexpression of the ERG gene was first discovered in patients with complex karyotypes and abnormal chromosome 21 [34,52]. Marcucci, et al showed that in patients less than 60 years old with de novo NC-AML, those patients expressing the highest levels of ERG (the top 25\%) have a worse cumulative incidence of relapse (CIR) and OS. In this analysis, ERG over-expression predicted a shorter survival only in patients with low BAALC expression. Though more study is needed to confirm these results, ERG overexpression in NC-AML not only predicts an adverse clinical outcome, but also appears to be associated with a specific molecular signature [51].

As the ERG gene is located on chromosome 21, it has been speculated that ERG expression may play a role in the pathogenesis of acute leukemia in patients with Down's syndrome. Patients with Down's syndrome are known to have a higher incidence of acute leukemia [53]. The high ERG expression may also be related to acute megakaryoblastic leukemia (FAB-M7) which is associated with trisomy 21 [54].

\section{AFIq expression}

Two small studies conducted by Tse et al suggest that elevated AF1q expression is associated with poor outcomes both in pediatric AML and adult myelodysplastic syndrome (MDS) [55,56]. In the pediatric study, AF1q expression in AML patients varied from 0 to 154 -fold compared with normal marrow and increasing AF1q expression level was associated with worsening survival with a hazard ratio of 1.02 per fold in AF1q expression ( $p$ $=0.032$ ). High AF1q expression was related to poor survival in univariate and multivariate models without association with any specific adverse cytogenetics [55]. The AF1q expression levels in the MDS study (total of 47 patients) suggested a statistically significant correlation with IPSS and AF1q expression level in high risk MDS [56]. Consistent with the findings in the pediatric AML study, MDS patients with high AF1q expression have an increased hazard ratio of death from MDS and relapse after allogeneic stem cell transplantation with correlation of specific poor cytogenetics. These observations led to a hypothesis that elevated AF1q expression might serve an adverse molecular marker for poor prognosis in AML patients with normal cytogenetics.

Recently, Strunk et al examined AF1q expression in 290 adult NC-AML patients (aged <60). They found NC-AML patients with low AF1q expression (AF1qlow) had better OS ( $p=0.026)$ and CR rate with initial induction chemotherapy $(\mathrm{p}=0.06)$ compared to high AF1q expressing patients (AF1qhigh). The AF1 $\mathrm{q}^{\text {high }}$ patients had a significantly greater incidence of concurrent FLT3-ITD. A sub- 
group of the AF1 $q^{\text {high }}$ patients who received allogeneic stem cell transplantation (SCT) had a significant better relapse-free survival compared to patients who received chemotherapy/autologous SCT $(\mathrm{p}=0.04)$. This suggests that high AF1q expression is a poor prognostic marker for adult NC-AML patients and may help direct post-induction treatment strategies.

\section{Gene expression Profiling}

Normal cytogenetics are detected pretreatment in approximately $45 \%$ of patients with de novo acute myeloid leukemia; thus, this constitutes the single largest cytogenetic group of AML. Recently, molecular genetic alterations with prognostic significance have been reported in these patients. They include internal tandem duplication of the FLT3 gene, partial tandem duplication of the MLL gene, mutations of the CEBP $\alpha$ and NPM1 genes and aberrant expression of the BAALC, ERG and MN1 genes. Additionally, gene-expression profiling has been applied to identify prognostically relevant subgroups [57].

Gene expression studies have identified that the majority of NC-AML patients fall into specific clusters that exhibit similar gene expression profiles. The identification of these clusters may not only be useful for diagnostic purposes, but also may help guide prognosis and therapeutic approaches. For example, NC-AML patients were found to up-regulate class I homeobox A and B gene families [58]. In another study, DNA microarray experiments identified two distinct subgroups of NC-AML including one that was closely related to the gene signatures observed in AML with translocations. In this study, NC-AML patients in the "translocation-like" group had a superior prognosis to the other group [57]. Similarly, a separate study also found two distinct gene expression clusters in NC-AML patients with significantly different survival. Using a panel of 133 genes, it was possible to predict the clinical outcome of NC-AML patients [59]. NC-AML patients in the cluster with worse survival were more likely to harbor FLT3 mutations and were more commonly diagnosed with specific AML subtypes (FAB M1 and M2). Bullinger's observation was recently validated by a Cancer and Leukemia Group B (CALGB) study that used a different microarray platform and had a longer follow up [60]. Gene-expression profiling allows a comprehensive classification of AML that includes previously identified genetically defined subgroups and a novel cluster with an adverse prognosis [59]. In the future, gene expression profiling studies will likely play a role clinically in molecularly risk stratifying NCAML patients as well as further elucidating the biology of NC-AML.

\section{Minimal Residual Disease}

Minimal residual disease (MRD) can provide an early indication of potential relapse in AML post-treatment.
There has been some initial evaluation of the utility of FLT3-ITD, CEBP $\alpha$, ERG, NPM1, and MLL in MRD whereas AF1q, MN-1, and BAALC have not. The impact of FLT3 was analyzed in 11 patients. All of the six patients with positive quantitative real-time polymerase chain reaction (RQ-PCR) post-treatment eventually relapsed [33]. Realtime quantitative PCR has also been used to evaluate MRD in patients carrying NPM1 mutations at time of diagnosis. Decreasing NPM1 copy number correlated with response to therapy and in four cases followed posttherapy, rising copy number preceded hematological relapse [13]. Additional evaluation in the post-transplant setting showed that all patients who remained NPM1 mutant positive after transplant relapsed and all those who had increases in mutation copies post-transplant relapsed as well [61]. Comparison of $\mathrm{CEBP} \alpha$ mutational status between diagnosis and relapse in AML was first investigated by Tiesmeier et al [62]. Two of 26 patients that relapsed had mutated $\mathrm{CEBP} \alpha$ which persistent posttreatment suggesting a concordance between presentation and relapse. As approximately $60 \%$ of CEBP $\alpha$ mutations are insertion or deletions, they are an amenable to MRD monitoring by RQ-PCR [63]. One case study have also reported the utility of RT-PCR for detecting ERG MRD. The patient had a negative ERG fusion gene after transplant which then recurred at time of relapse [64]. A larger analysis of 19 patients conducted by Kong et al. noted four types of TLS/FUS-ERG chimeric transcripts via RTPCR. The transcripts were detectable at diagnosis as well as during remission and relapse suggesting resistance to conventional chemotherapy [65]. Finally, RT-PCR has also been used to evaluate expression levels of partial tandem duplications in the MLL gene. Expression levels in 16 patients were analyzed at time of diagnosis and at relapse and found to be equivalent. Additionally, molecular relapse was detected 35 days before clinical relapse in two patients [39]. Thus, MLL-PTD was suggested as a target for MRD detection. Currently, MRD monitoring via these molecular markers is not commercially available to the community physician, but these studies provide insight to their future potential in MRD monitoring.

\section{Conclusion}

Though NC-AML comprises the single largest subgroup of $\mathrm{AML}$, these patients pose considerable challenges in diagnosis, risk stratification, and post-treatment monitoring for minimal residual disease. Gene expression and profiling studies have shown that NC-AML is very heterogeneous at the molecular level. Multiple studies have shown that NC-AML patients usually exhibit two or more genetic aberrations. While assessment of these molecular prognostic markers is not widely available to the community physician outside of a clinical trial, future studies will help to further validate the prognostic importance of these altered genetic abnormalities in systemic multivariate 
analysis in the NC-AML patients. Once the prognostic importance of these genetic abnormalities is clear, it may be possible to appropriately tailor the aggressiveness of therapy to NC-AML patients. Further, these studies also have the potential to identify novel therapeutic targets that may be used to design targeted therapies. In the future, specific genetic abnormalities may be profiled in AML patients in a similar manner to the immunophenotyping that is currently done by flow cytometry to obtain information on accurate diagnosis, prognosis, and disease monitoring.

\section{Competing interests}

The authors declare that they have no competing interests.

\section{Authors' contributions}

All authors participated in the drafting of the manuscript. TG edited the manuscript and WT and TG read and approved the final manuscript.

\section{Acknowledgements}

The University of Colorado Denver Medical Oncology/Hematology Program

\section{References}

I. Kell J: Emerging treatments in acute myeloid leukaemia. Expert Opin Emerg Drugs 2004, 9(I):55-71.

2. Estey EH: General approach to, and perspectives on clinical research in older patients with newly diagnosed acute myeloid leukemia. Semin Hematol 2006, 43(2):89-95.

3. Tallmann MS: Curative therapeutic approaches to APL. Ann Hematol 2004, 83(SuppI I):S8I-S82.

4. Mrózek K, Heinonen K, de la Chapelle A, Bloomfield CD: Clinical significance of cytogenetics in acute myeloid leukemia. Semin Oncol 1997, 24(I): 17-3I.

5. Slovak ML, Kopecky KJ, Cassileth PA, Harrington DH, Theil KS, Mohamed A, Paietta E, Willman CL, Head DR, Rowe JM, Forman SJ, Appelbaum FR: Karyotypic analysis predicts outcome of preremission and postremission therapy in adult acute myeloid leukemia: a Southwest Oncology Group/Eastern Cooperative Oncology Group Study. Blood 2000, 96( I3):4075-4083.

6. Verhaak RG, Goudswaard CS, van Putten W, Bijl MA, Sanders MA, Hugens W, Uitterlinden AG, Erpelinck CA, Delwel R, Löwenberg B, Valk PJ: Mutations in nucleophosmin (NPMI) in acute myeloid leukemia (AML): association with other gene abnormalities and previously established gene expression signatures and their favorable prognostic significance. Blood 2005, 106( I 2):3747-3754.

7. Chen WG, Rassidakis GZ, Medeiros LJ: Nucleophosmin gene mutations in acute myeloid leukemia. Arch Pathol Lab Med 2006, I30(II): 1687-1692.

8. Falini B, Mecucci C, Tiacci E, Alcalay M, Rosati R, Pasqualucci L, La Starza R, Diverio D, Colombo E, Santucci A, Bigerna B, Pacini R, Pucciarini A, Liso A, Vignetti M, Fazi P, Meani N, Pettirossi V, Saglio G, Mandelli F, Lo-Coco F, Pelicci PG, Martelli MF: Cytoplasmic nucleophosmin in acute myelogenous leukemia with a normal karyotype. N Engl J Med 2005, 352(3):254-266.

9. Falini B, Nicoletti I, Martelli MF, Mecucci C: Acute myeloid leukemia carrying cytoplasmic/mutated nucleophosmin (NPMc+ AML): biological and clinical features. Blood 2007, 109(3):874-885.

10. Grisendi S, Mecucci C, Falini B, Pandolfi PP: Nucleophosmin and cancer. Nat Rev Cancer 2006, 6(7):493-505.

II. Larramendy ML, Niini T, Elonen E, Nagy B, Ollila J, Vihinen M, Knuutila $S$ : Over-expression of translocation-associated fusion genes of FGFRI, MYC, NPMI, and DEK, but absence of the translo- cations in acute myeloid leukemia. A microarray analysis. Haematologica 2002, 87(6):569-577.

12. Noguera NI, Ammatuna E, Zangrilli D, Lavorgna S, Divona M, Buccisano F, Amadori S, Mecucci C, Falini B, Lo-Coco F: Simultaneous detection of NPMI and FLT3-ITD mutations by capillary electrophoresis in acute myeloid leukemia. Leukemia 2005, 19(8): | 479- | 482

13. Gorello P, Cazzaniga G, Alberti F, Dell'Oro MG, Gottardi E, Specchia G, Roti G, Rosati R, Martelli MF, Diverio D, Lo Coco F, Biondi A, Saglio G, Mecucci C, Falini B: Quantitative assessment of minimal residual disease in acute myeloid leukemia carrying nucleophosmin (NPMI) gene mutations. Leukemia 2006, 20(6): $1103-1108$

14. Döhner K, Schlenk RF, Habdank M, Scholl C, Rücker FG, Corbacioglu A, Bullinger L, Fröhling S, Döhner H: Mutant nucleophosmin (NPMI) predicts favorable prognosis in younger adults with acute myeloid leukemia and normal cytogenetics: interaction with other gene mutations. Blood 2005, 106( I 2):3740-3746.

15. Schnittger S, Schoch C, Kern W, Mecucci C, Tschulik C, Martelli MF, Haferlach T, Hiddemann W, Falini B: Nucleophosmin gene mutations are predictors of favorable prognosis in acute myelogenous leukemia with a normal karyotype. Blood 2005, 106(I2):3733-3739.

16. Thiede C, Koch S, Creutzig E, Steudel C, Illmer T, Schaich M, Ehninger G: Prevalence and prognostic impact of NPMI mutations in I 485 adult patients with acute myeloid leukemia (AML). Blood 2006, I07(10):40II-4020.

17. Boissel N, Renneville A, Biggio V, Philippe N, Thomas X, Cayuela JM, Terre C, Tigaud I, Castaigne S, Raffoux E, De Botton S, Fenaux P, Dombret $\mathrm{H}$, Preudhomme C: Prevalence, clinical profile, and prognosis of NPM mutations in AML with normal karyotype. Blood 2005, 106(10):3618-3620.

18. Suzuki T, Kiyoi H, Ozeki K, Tomita A, Yamaji S, Suzuki R, Kodera $Y$, Miyawaki S, Asou N, Kuriyama K, Yagasaki F, Shimazaki C, Akiyama H, Nishimura M, Motoji T, Shinagawa K, Takeshita A, Ueda R, Kinoshita T, Emi N, Naoe T: Clinical characteristics and prognostic implications of NPMI mutations in acute myeloid leukemia. Blood 2005, 106(8):2854-286I.

19. Kiyoi H, Naoe T: Biology, clinical relevance, and molecularly targeted therapy in acute leukemia with FLT3 mutation. Int J Hematol 2006, 83(4):30I-308.

20. Zheng R, Small D: Mutant FLT3 signaling contributes to a block in myeloid differentiation. Leuk Lymphoma 2005, 46(1 2): 1679-1687.

21. Fröhling S, Schlenk RF, Breitruck J, Benner A, Kreitmeier S, Tobis K, Döhner H, Döhner K: Prognostic significance of activating FLT3 mutations in younger adults ( 16 to 60 years) with acute myeloid leukemia and normal cytogenetics: a study of the AML Study Group UIm. Blood 2002, I00(13):4372-4380.

22. Yamamoto $Y$, Kiyoi H, Nakano $Y$, Suzuki R, Kodera $Y$, Miyawaki $S$, Asou N, Kuriyama K, Yagasaki F, Shimazaki C, Akiyama H, Saito K, Nishimura M, Motoji T, Shinagawa K, Takeshita A, Saito H, Ueda R, Ohno R, Naoe T: Activating mutation of D835 within the activation loop of FLT3 in human hematologic malignancies. Blood 200I, 97(8):2434-2439.

23. Kainz B, Heintel D, Marculescu R, Schwarzinger I, Sperr W, Le T, Weltermann A, Fonatsch C, Haas OA, Mannhalter C, Lechner K, Jaeger U: Variable prognostic value of FLT3 internal tandem duplications in patients with de novo AML and a normal karyotype, t(15;17), t(8;2I) or inv(16). Hematol J 2002, 3(6):283-289.

24. Ciolli S, Vannucchi AM, Leoni F, Nozzoli C, Longo G, Salati A, Pancrazzi A, Bianchi L, Gigli F, Bosi A: Internal tandem duplications of FIt3 gene (FIt3/ITD) predicts a poor post-remission outcome in adult patients with acute non-promyelocytic leukemia. Leuk Lymphoma 2004, 45(I):73-78.

25. Bienz M, Ludwig M, Leibundgut EO, Mueller BU, Ratschiller D, Solenthaler M, Fey MF, Pabst T: Risk assessment in patients with acute myeloid leukemia and a normal karyotype. Clin Cancer Res 2005, II (4): | 41 6- I 424.

26. Stirewalt DL, Kopecky KJ, Meshinchi S, Engel JH, Pogosova-Agadjanyan EL, Linsley J, Slovak ML, Willman CL, Radich JP: Size of FLT3 internal tandem duplication has prognostic significance in patients with acute myeloid leukemia. Blood 2006, 107(9):3724-3726. 
27. Whitman SP, Archer KJ, Feng L, Baldus C, Becknell B, Carlson BD, Carroll AJ, Mrózek K, Vardiman JW, George SL, Kolitz JE, Larson RA, Bloomfield CD, Caligiuri MA: Absence of the wild-type allele predicts poor prognosis in adult de novo acute myeloid leukemia with normal cytogenetics and the internal tandem duplication of FLT3: a cancer and leukemia group B study. Cancer Res 200I, 6I (19):7233-7239.

28. Thiede C, Steudel C, Mohr B, Schaich M, Schäkel U, Platzbecker U, Wermke M, Bornhäuser M, Ritter M, Neubauer A, Ehninger G, Illmer $\mathrm{T}$ : Analysis of FLT3-activating mutations in 979 patients with acute myelogenous leukemia: association with FAB subtypes and identification of subgroups with poor prognosis. Blood 2002, 99(I 2):4326-4335.

29. Ozeki K, Kiyoi H, Hirose Y, Iwai M, Ninomiya M, Kodera Y, Miyawaki S, Kuriyama K, Shimazaki C, Akiyama H, Nishimura M, Motoji T, Shinagawa K, Takeshita A, Ueda R, Ohno R, Emi N, Naoe T: Biologic and clinical significance of the FLT3 transcript level in acute myeloid leukemia. Blood 2004, I03(5): 1901-1908.

30. Gale RE, Hills R, Kottaridis PD, Srirangan S, Wheatley K, Burnett AK, Linch DC: No evidence that FLT3 status should be considered as an indicator for transplantation in acute myeloid leukemia (AML): an analysis of II 35 patients, excluding acute promyelocytic leukemia, from the UK MRC AMLI 0 and 12 trials. Blood 2005, 106(1 0):N3658-3665.

31. Sritana N, Auewarakul CU: KIT and FLT3 receptor tyrosine kinase mutations in acute myeloid leukemia with favorable cytogenetics: Two novel mutations and selective occurrence in leukemia subtypes and age groups. Experimental and Molecular Pathology 2008, 85:227-23I.

32. Sternberg DW, Licht JD: Therapeutic intervention in leukemias that express the activated fms-like tyrosine kinase 3 (FLT3): opportunities and challenges. Curr Opin Hematol 2005, I2(I):7-13.

33. Scholl S, Loncarevic IF, Krause C, Kunert C, Clement JH, Höffken K: Minimal residual disease based on patient specific FIt3-ITD and -ITT mutations in acute myeloid leukemia. Leuk Res 2005 29(7):849-853.

34. Mrózek K, Heinonen K, Theil KS, Bloomfield CD: Spectral karyotyping in patients with acute myeloid leukemia and a complex karyotype shows hidden aberrations, including recurrent overrepresentation of 2 Iq, 1 Iq, and 22q. Genes Chromosomes Cancer 2002, 34(2): I37-153.

35. Yu BD, Hess JL, Horning SE, Brown GA, Korsmeyer SJ: Altered Hox expression and segmental identity in MII-mutant mice. Nature 1995, 378(6556):505-508.

36. Whitman SP, Liu S, Vukosavljevic T, Rush LJ, Yu L, Liu C, Klisovic MI, Maharry K, Guimond M, Strout MP, Becknell B, Dorrance A, Klisovic RB, Plass C, Bloomfield CD, Marcucci G, Caligiuri MA: The MLL partial tandem duplication: evidence for recessive gain-offunction in acute myeloid leukemia identifies a novel patient subgroup for molecular-targeted therapy. Blood 2005 106(I):345-352

37. Döhner K, Tobis K, Ulrich R, Fröhling S, Benner A, Schlenk RF, Döhner $\mathrm{H}$ : Prognostic significance of partial tandem duplications of the MLL gene in adult patients 16 to 60 years old with acute myeloid leukemia and normal cytogenetics: a study of the Acute Myeloid Leukemia Study Group UIm. J Clin Oncol 2002, 20(I5):3254-326I.

38. Schnittger S, Kinkelin U, Schoch C, Heinecke A, Haase D, Haferlach T, Büchner T, Wörmann B, Hiddemann W, Griesinger F: Screening for MLL tandem duplication in 387 unselected patients with AML identify a prognostically unfavorable subset of AML. Leukemia 2000, I4(5):796-804.

39. Weisser M, Kern W, Schoch C, Hiddemann W, Haferlach T, Schnittger S: Risk assessment by monitoring expression levels of partial tandem duplications in the MLL gene in acute myeloid leukemia during therapy. Haematologica 2005, 90(7):88I-889.

40. Pabst T, Mueller BU, Zhang P, Radomska HS, Narravula S, Schnittger S, Behre G, Hiddemann W, Tenen DG: Dominant-negative mutations of CEBPA, encoding CCAAT/enhancer binding protein-alpha (C/EBPalpha), in acute myeloid leukemia. Nat Genet 200I, 27(3):263-270.

4I. Barjesteh van Waalwijk van Doorn-Khosrovani S, Erpelinck C, Meijer J, van Oosterhoud S, van Putten WL, Valk PJ, Berna Beverloo H, Tenen DG, Löwenberg B, Delwel R: Biallelic mutations in the
CEBPA gene and low CEBPA expression levels as prognostic markers in intermediate-risk AML. Hematol J 2003, 4(I):31-40. 42. Fröhling S, Schlenk RF, Stolze I, Bihlmayr J, Benner A, Kreitmeier S, Tobis K, Döhner H, Döhner K: CEBPA mutations in younger adults with acute myeloid leukemia and normal cytogenetics: prognostic relevance and analysis of cooperating mutations. I Clin Oncol 2004, 22(4):624-633.

43. Preudhomme C, Sagot C, Boissel N, Cayuela JM, Tigaud I, de Botton S, Thomas X, Raffoux E, Lamandin C, Castaigne S, Fenaux P, Dombret $\mathrm{H}$ : Favorable prognostic significance of CEBPA mutations in patients with de novo acute myeloid leukemia: a study from the Acute Leukemia French Association (ALFA). Blood 2002, I00(8):27I7-2723

44. Tanner SM, Austin JL, Leone G, Rush LJ, Plass C, Heinonen K, Mrózek K, Sill H, Knuutila S, Kolitz JE, Archer KJ, Caligiuri MA, Bloomfield CD, de La Chapelle A: BAALC, the human member of a novel mammalian neuroectoderm gene lineage, is implicated in hematopoiesis and acute leukemia. Proc Natl Acad Sci USA 200 I, 98(24): $1390 \mid-13906$

45. Baldus CD, Tanner SM, Kusewitt DF, Liyanarachchi S, Choi C, Caligiuri MA, Bloomfield $C D$, de la Chapelle A: BAALC, a novel marker of human hematopoietic progenitor cells. Exp Hematol 2003, 3 I(II):105I-1056.

46. Baldus CD, Tanner SM, Ruppert AS, Whitman SP, Archer KJ, Marcucci G, Caligiuri MA, Carroll AJ, Vardiman JW, Powell BL, Allen SL, Moore JO, Larson RA, Kolitz JE, de la Chapelle A, Bloomfield CD: BAALC expression predicts clinical outcome of de novo acute myeloid leukemia patients with normal cytogenetics: a Cancer and Leukemia Group B Study. Blood 2003, 102(5):1613-1618.

47. Baldus CD, Tanner SM, Ruppert AS, Whitman SP, Archer KJ, Marcucci G, Caligiuri MA, Carroll AJ, Vardiman JW, Powell BL, Allen SL, Moore JO, Larson RA, Kolitz JE, de la Chapelle A, Bloomfield CD: BAALC expression and FLT3 internal tandem duplication mutations in acute myeloid leukemia patients with normal cytogenetics: prognostic implications. J Clin Oncol 2006, 24(5):790-797.

48. van Wely KH, Molijn AC, Buijs A, Meester-Smoor MA, Aarnoudse AJ, Hellemons A, den Besten P, Grosveld GC, Zwarthoff EC: The MN I oncoprotein synergizes with coactivators RAC3 and p300 in RAR-RXR-mediated transcription. Oncogene 2003, 22(5):699-709.

49. Kawagoe H, Grosveld GC: Conditional MNI-TEL knock-in mice develop acute myeloid leukemia in conjunction with overexpression of HOXA9. Blood 2005, 106:4269-4277.

50. Heuser M, Beutel G, Krauter J, Döhner K, von Neuhoff N, Schlegelberger B, Ganser A: High meningioma I (MNI) expression as a predictor for poor outcome in acute myeloid leukemia with normal cytogenetics. Blood 2006, I 08( I 2):3898-3905.

51. Marcucci G, Baldus CD, Ruppert AS, Radmacher MD, Mrózek K, Whitman SP, Kolitz JE, Edwards CG, Vardiman JW, Powell BL, Baer MR, Moore JO, Perrotti D, Caligiuri MA, Carroll AJ, Larson RA, de la Chapelle A, Bloomfield CD: Over-expression of the ETS-related gene, ERG, predicts a worse outcome in acute myeloid leukemia with normal karyotype: a Cancer and Leukemia Group B study. I Clin Oncol 2005, 23(36):9234-92.

52. Baldus CD, Liyanarachchi S, Mrózek K, Auer H, Tanner SM, Guimond M, Ruppert AS, Mohamed N, Davuluri RV, Caligiuri MA, Bloomfield $C D$, de la Chapelle A: Acute myeloid leukemia with complex karyotypes and abnormal chromosome 21: Amplification discloses over-expression of APP, ETS2, and ERG genes. Proc Natl Acad Sci USA 2004, I 0 I(I I):3915-3920.

53. Papas TS, Watson DK, Sacchi N, Fujiwara S, Seth AK, Fisher RJ, Bhat NK, Mavrothalassitis G, Koizumi S, Jorcyk CL: ETS family of genes in leukemia and Down syndrome. Am J Med Genet Suppl 1990, 7:25I-26I.

54. Rainis L, Toki T, Pimanda JE, Rosenthal E, Machol K, Strehl S, Göttgens $B$, Ito $E$, Izraeli S: The proto-oncogene ERG in megakaryoblastic leukemias. Cancer Res 2005, 65(I 7):7596-602.

55. Tse W, Meshinchi S, Alonzo TA, Stirewalt DL, Gerbing RB, Woods WG, Appelbaum FR, Radich JP: Elevated expression of the AFIq gene, an MLL fusion partner, is an independent adverse prognostic factor in pediatric acute myeloid leukemia. Blood 2004, 104:3058-3063. 
56. Tse W, Joachim DH, Stirewalt D, Appelbaum FR, Radich J, Gooley T: Increased AF I q gene expression in high-risk myelodysplastic syndrome. $\mathrm{Br} J$ Haematol 2005, I 28(2):2 I 8-220.

57. Vey N, Mozziconacci MJ, Groulet-Martinec A, Debono S, Finetti P, Carbuccia N, Beillard E, Devilard E, Arnoulet C, Coso D, Sainty D, Xerri L, Stoppa AM, Lafage-Pochitaloff M, Nguyen C, Houlgatte R, Blaise D, Maraninchi D, Birg F, Birnbaum D, Bertucci F: Identification of new classes among acute myelogenous leukaemias with normal karyotype using gene expression profiling. Oncogene 2004, 23(58):938I-9391.

58. Debernardi S, Lillington DM, Chaplin T, Tomlinson S, Amess J, Rohatiner A, Lister TA, Young BD: Genome-wide analysis of acute myeloid leukemia with normal karyotype reveals a unique pattern of homeobox gene expression distinct from those with translocation-mediated fusion events. Genes Chromosomes Cancer 2003, 37(2): $149-158$.

59. Bullinger L, Döhner K, Bair E, Fröhling S, Schlenk RF, Tibshirani R, Döhner H, Pollack JR: Use of gene-expression profiling to identify prognostic subclasses in adult acute myeloid leukemia. $\mathrm{N}$ Engl] Med 2004, 350(16): 1605-1616.

60. Radmacher MD, Marcucci G, Ruppert AS, Mrózek K, Whitman SP, Vardiman JW, Paschka P, Vukosavljevic T, Baldus CD, Kolitz JE, Caligiuri MA, Larson RA, Bloomfield CD: Independent confirmation of a prognostic gene-expression signature in adult acute myeloid leukemia with a normal karyotype: a Cancer and Leukemia Group B study. Blood 2006, 108:1677-1683.

6I. Bacher U, Badbaran A, Fehse B, Zabelina T, Zander AR, Kröger N: Quantitative monitoring of NPMI mutations provides a valid minimal residual disease parameter following allogeneic stem cell transplantation. Experimental Hematology 2009, 37(I): I35-| 42.

62. Tiesmeier J, Czwalinna A, Muller-Tidow C, Krauter J, Serve H, Heil G, Ganser A, Verbeek W: Evidence for allelic evolution of $\mathbf{C l}$ EBPalpha mutations in acute myeloid leukemia. $\mathrm{Br} J$ Haematol. 2003, I 23(3):413-4I9.

63. Smith LL, Pearce D, Smith ML, Jenner M, Lister TA, Bonnet D, Goff L, Fitzgibbon J: Development of quantitative real-timepolymerase chain reaction method for monitoring CEBPA mutations in normal karyotype acute myeloid leukaemia. $\mathrm{Br} J$ Haematol. 2006, I33(I): 103-105.

64. Okoshi Y, Shimizu S, Kajima H, Obara N, Mukai HY, Komeno T, Hasegawa Y, Mori N, Nagasawa T: Detection of minimal residual disease is a patient having acute myelogenous leukemia with $t(16 ; 21)(p I I ; q 22)$ treated by allogeneic bone marrow transplantation. Acta Haematologica 200 I, 105:45-48.

65. Kong XT, Ida K, Ichikawa H, Shimizu K, Ohki M, Maseki N, Kaneko Y, Sako M, Kobayashi Y, Tojou A, Miura I, Kakuda H, Funabiki T, Horibe K, Hamaguchi H, Akiyama Y, Bessho F, Yanagisawa M, Hayashi Y: Consistent detection of TLS/FUS-ERG chimeric transcripts in acute myeloid leukemia with $t(16 ; 2 I)(p I I ; q 22)$ and identification of a novel transcript. Blood 1997, 90: I 192-I I99.

Publish with Bio Med Central and every scientist can read your work free of charge

"BioMed Central will be the most significant development for disseminating the results of biomedical research in our lifetime. "

Sir Paul Nurse, Cancer Research UK

Your research papers will be:

- available free of charge to the entire biomedical community

- peer reviewed and published immediately upon acceptance

- cited in PubMed and archived on PubMed Central

- yours - you keep the copyright
BioMedcentral 